\title{
METHODOLOGY OF CRIME PREVENTION TRAINING
}

\author{
Krastyu KRASTEV, Marya DONCHEVA \\ "Vasil Levski "National Military University, Veliko Tarnovo, Bulgaria \\ krustev_kr@abv.bg, mvdoncheva@gmail.com
}

\begin{abstract}
According to the Military Police Act the Military Police Service, alone or in collaboration with other security services and public order services, carries out activities to prevent crimes. The purpose of this report is to represent the methodology of crime prevention training of the military police cadets at Vasil Levski NMU. In order to achieve the research goals, the theoretical and methodological aspects are analyzed as well as the main pedagogical tools and the possibilities of applying modern training methods. The methodology of the research includes an analysis of the current legal and regulatory legislation, comparative analysis and formulation of some general conclusions for improving crime prevention training.
\end{abstract}

Keywords: crime, prevention, training, military police

\section{Introduction}

The Military Police Service is a specialized structure for the protection of order and security in the Ministry of Defense, in the structures directly subordinated to the Minister of Defense and in the Bulgarian Army with the task to guarantee the security of their personnel. [1]

Pursuant to Article 2 (1) para (6) of the Military Police Act, the Military Police Service, alone or in collaboration with other security services and public order services, carries out activities to prevent, investigate and detect offenses of a general nature and police registration of persons. [2]

The subject of this report is the methodology of training in prevention, investigation and detection of criminal offenses of a general nature.

The focus of the report is the training process of the students in the Military Police specialization at Vasil Levski National Military University.

The objective of this report is to present the methodology for preparing future Military
Police officers for prevention of crimes. In order to achieve the stated goal, the following tasks have been defined:

1. Analyze the theoretical and methodological aspects of training.

2. Characterize and analyze the pedagogical tools and the possibilities of applying modern training methods.

3. Draw conclusions on the possibilities of improving the training of students from the Military Police specialty in relation to the role of the Military Police Service in the prevention, investigation and detection of crimes of a general nature.

The methodology of the study includes an analysis of the current legal and regulatory legislation, comparative analysis and formulation of some general conclusions. This report does not claim exhaustiveness, but can serve as a good basis for further research in this area. 


\section{Theoretical-methodological aspects of crime prevention training.}

\subsection{Training objectives and tasks.}

The main objective of the course is to ensure methodologically correct sequence in the study of the training material in accordance with its complexity and consistency, by establishing a connection with other subjects from the curriculum and their sequence throughout the overall the training. [3]

As a result of the training, the students acquire new knowledge of the general characteristics, the object and the subject of the crimes of general nature and the military crimes, the crimes against the defense capability of the Republic; the procedure for exemption from criminal liability (Article 406 para (3) and (4) of the Criminal Code); some proceedings of characteristic military crimes - crimes against subordination and military unit, desertion from military service; war crimes, etc. [4]

As a result of the exercises included in the program, the trainees should build new capabilities to fully perform the analytical, prognostic and information functions ensuing from their functional duties, to fully organize and firmly manage the actions of the military-police force under their command as well as to manage the process of collecting, analyzing and reporting operational information, law enforcement, prevention, detection and investigation of crime, collection and exchange of information.

\subsection{Methods of presenting new information.}

The main method of presenting the new information is the oral presentation of the training material. Several variations of oral presentation are the following: narrative, explanation, lecture, debate with an opponent. [5]

The lecture is a kind of presentation that systematically and continuously develops a topic from the training curriculum. [6] It is the main method of oral presentation of the training material. The lecture provides a comprehensive insight into complex concepts, laws and ideas. In the lecture an important place is the fact-finding, the comparison, the scientific proof of one or another thesis, the in-depth analysis, the scientific reports and conclusions. The narrative is a continuous account of certain facts and problems. Through it, new knowledge is presented to the learners, but it also provokes feelings, develops emotions, and forms a relationship. The emotional attitude of the teacher to the topic of the narrative is a distinctive feature of particular importance. The expressiveness of the narrative is enhanced by intonation, mimics, and gestures. [7]

In a number of cases, the explanation is an independent didactic method, but it can also be an integral part of other training methods. In this method, rational arguments prevail. The main purpose of the explanation is to help the learner understand the essence of knowledge that is to be conveyed and mastered. [8] For more complete and effective acquisition of the course material in the course of the learning process, group consultations with specialists - operative officers or investigative policemen are envisaged.

A debate with an opponent is, by its very nature, a method close to the lecture. It is distinguished by the fact that it enables clarification of the issues raised during the presentation of the material. A second lecturer or a well-trained learner who is empowered to ask the lecturer questions, to clarify any ambiguity, to express opinion on the theoretical material discussed, is involved in the class work.

\subsection{Methods of discussing the training material.}

Whereas the oral presentation of the training material implies a one-sided relay of the knowledge by the teacher, the discussion has definitely a bilateral nature. It stimulates the process of exchange of knowledge and ideas between the trainer on one side and the trainees on the other. 
Furthermore, the lecturer tests the trainees' knowledge, encourages creative thinking in the interpretation of the particular topic. In its essence, the discussion is a questionresponse form of training, where questions can be asked both by the teacher and the learners.

The group exercise is similar to the question-and-answer session. The objective is the same - a sequence of questions and answers aiming at collective search for the correct ones.

The seminar is an in-depth and creative discussion of a particular topic, included in the curriculum. It is characterized by theoretical complexity, argumentation and proof of theses. At the seminar, after the opening speech of the teacher, reports are usually delivered to highlight problems and unresolved issues on the topic, and they provide material for reflection to those participating in the seminar. The learners express their opinion in accordance with the regulatory documents, with the literature on the issues under consideration, make suggestions, and have debates with the specialists. The organization of the seminar depends to a large extent on the teacher, who has to consider his or her plan well, to assist the speakers, to organize individual and group consultations, to indicate the necessary literature. Of great importance for the seminar is the preliminary preparation of the trainees. Their theoretical knowledge, practical experience and interest in the subject are prerequisites for the successful completion of the seminar and contribute to the achievement of the learning objectives.

During the seminar, the lecturer not only examines the preparation of the trainees, but extends and enhances their knowledge on the subject. In his closing speech the lecturer leaves the discussion open, indicates the generally accepted or most acceptable solution, but the search for better options continues in the training and practical work of the learners.

\section{Characteristics and analysis of the pedagogical methods and approaches. 3.1. Interactivity of the training.}

The analysis of modern approaches in the field of higher education reveals that the interactive educational environment is established in the educational space in accordance with the current educational tendencies for the growth the impact on personality on subject-object basis and the subordination relations on subject-tosubject interaction and relationships of interdependence. [7]

On the other hand, in the military education system, the interactive environment is characterized by the shift of the center of gravity from providing knowledge to the trainees to their self-preparation through new knowledge, new activity, new communication. The ultimate goal is the creation of a new learning culture of the cadets, through a new theory for the subject based on multifaceted contacts with the environment and incorporation into the unity of the products and the mechanisms of thinking and action.

The creation of an interactive educational environment is also a prerequisite for the adaptation of the system of methods, forms and means of training used to meet the requirements of the new paradigm for the creation of a European Higher Education Space and a high quality of the pedagogical process through pedagogical interaction. [8] As determinants of the methods to be used, it is possible to use the goals that the lecturer sets; the specifics of the discipline; the type of the training task; the cognitive abilities of the students; the competencies of the lecturer and of the cadets for the application of the individual methods; the preferences of the two subjects; the availability of relevant facilities; the arrangement of the working stations in the classroom, etc.

Depending on the selected methods and the specific learning tasks, the academic staff of the department prepares the necessary 
conditions for conducting the interactive training that facilitate the interaction.

Interactive learning methods play a key role in the interactive learning environment. A number of varieties have been taken from the theory of interactive training methods, and have been integrated in the training of cadets from the Military Police specialty.

Some of them are brainstorming (Osbourne,1942); synectics (Gordon,1961); creativity (Kaufmann\&oth,2002); checklists (Osbourne,1942); team training (Hopkins, 1984); cooperative learning (El Aronson,2011); research carried out in groups (Scharan,1976); SWOT analysis, pyramid, lightning, brain writing, avalanche (snowball), circle, panel discussion, traffic lights, aquarium, mind mapping etc. $[9,10]$

\subsection{Heuristic approaches to teaching.}

The Heuristic methods are divided in two main categories - methods used mainly for training and building of skills and abilities of heuristic thinking, and methods for stimulation in the process of immediate search for solutions. [11]

The knowledge acquisition model, presented in Figure 1, allows the effective implementation of modern training methods which provide the opportunity of mastering the training material in an individual way by each trainee. These are methods of searching for different approaches and directions for heuristic solutions. The following belong here: brainstorming, synectics, method of control questions, "liquidation of dead-end situations", "objects in focus" method.

For the effective training of the cadets from the Military Police Specialty, with regard to their future functions and duties in the prevention of crimes of a general nature, it is of fundamental importance for them to become familiar with the theory of criminal law.

According to the theory of criminal law, crime is a socially dangerous act committed at fault and declared to be punishable by law at the time it was committed. In principle, criminal laws, the substantive law under whose power responsibility should be sought for certain acts defined as crimes, cannot be given backward power i.e. in a subsequent legislative act a person cannot be considered criminally liable for acts or misconduct which have not been declared as such by the act of the moment of their material commitment. The opposite is in contradiction with international acts to which the Republic of Bulgaria is a party.

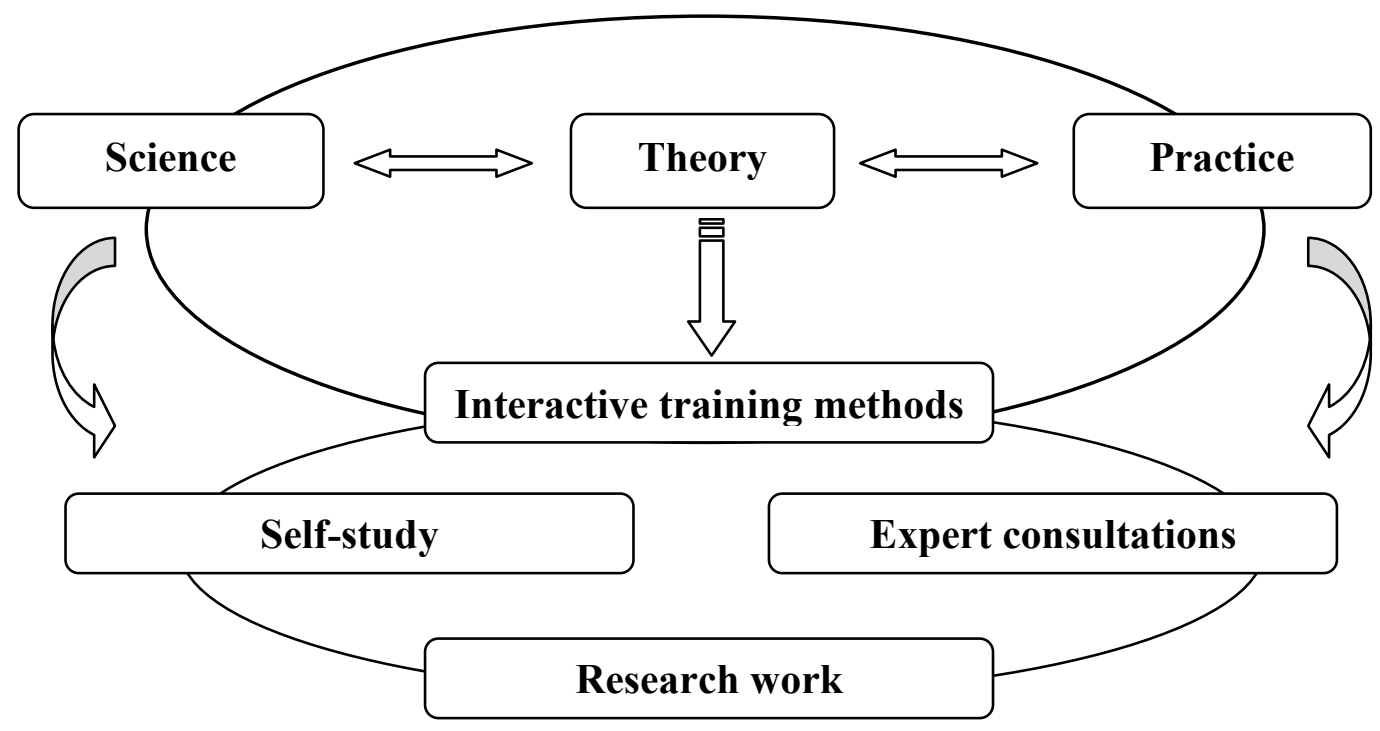

Figure 1 Heuristic model of knowledge acquisition 
The study and learning of the basic principles of criminal law is of particular importance in the theoretical module:

1. Principle of Legality - Article 5, paragraph 3 of the Constitution states that no one can be convicted of an act or omission which has not been declared by the law as a crime at the time of its committing. [12]

2. Principle of Democracy - Criminal law protects the interests of the whole society, of all people who are to one degree or another under Bulgarian jurisdiction.

3. Principle of Humanism - a combination of coercive and remedial impact on the perpetrator. Thus, the punishment is not only a pure retribution for the committed crime, but it also leads to the possibility for the guilty person to return to normal life in society; humanism requires that punishment be subordinated to certain purposes; the prejudice of the sentenced person's rights must not be an end in itself, be imposed solely on his own, or be directed at causing physical suffering or humiliating human dignity; the use of repression, also taking into account the effected violation of the rights of the victims of the crimes.

4. Principle of internationalism This basic requirement is related to the need for the Bulgarian state to provide criminal protection against criminal offenses of interest, even if they belong to another state or to foreign citizens without always directly affecting Bulgarian interests.

Another key element of the theoretical aspect is the types of crime. Under the Criminal Code of Bulgaria, the types of crimes are as follows: crimes against the republic - treachery, betrayal and espionage, diversion and harm, terrorism; crimes against the person - murder, body harm, defamation, kidnapping, coercion, confession, insult, defamation, rape, fornication, human trafficking; crimes against property - theft, robbery, embezzlement, fraud, extortion, property concealment, destruction and damage to property, abuse of trust; crimes against the monetary and credit system - falsification of money, securities and documents; crimes against marriage, family and youth polygamy, forced marriage, ransom for marriage, selling children, leaving children unattended; bribery, bribery, breach of official duties, over-execution of authority, misuse of power, abuse of office; computer crimes - hacking; life-threatening crimes blasting, arson, malicious flooding; crimes against public health and the environment poisoning, infection, environmental damage; war crimes - deviation from military service, non-compliance; crimes against peace and humanity - propaganda for war, genocide, apartheid, hostage taking, murder, torture and inhuman treatment of war prisoners and civilians.

Fault is a subjective element of the crime. It represents the psychological attitude of the perpetrator to his / her own deed, the socially dangerous consequences it causes, it is expressed through a particular act, receives a negative assessment from society and is expressed in the form of intention or negligence.

Intentional forms of fault (intention and self-conceit) are excluded from the factual error under the conditions of Art. 14 of Criminal Code, and negligence - when there is an accidental act under Art. 15 of CC. Acts done under Art. $16 \mathrm{CC}$ are not qualified as faulty. [13]

Table 1 Forms of fault

\begin{tabular}{|c|c|c|c|c|c|}
\hline-1 & 0 & 1 & 2 & 3 & 4 \\
\hline Not committed & $\begin{array}{c}\text { Accidental } \\
\text { Action }\end{array}$ & $\begin{array}{l}\text { Unintentional } \\
\text { Negligence }\end{array}$ & $\begin{array}{l}\text { Intentional } \\
\text { Negligence }\end{array}$ & $\begin{array}{c}\text { Indirect } \\
\text { Intent }\end{array}$ & $\begin{array}{l}\text { Direct } \\
\text { Intent }\end{array}$ \\
\hline
\end{tabular}




\section{Research results}

Regarding the possibilities for improving the training of the students from Military Police specialty in relation to the role of the Military Police in the prevention, investigation and detection of crimes of general nature, it is possible to formulate the following main conclusions:

1. Studying and enhancing the knowledge of the topics related to the prevention of crimes of a general nature is of fundamental importance for the development of the professional culture of future young officers of the Military Police Service.

2. Methodological and theoretical basis of the training and the preparation in the respective field are the application of the dialectical method of knowledge of the phenomena and the processes of the social reality, their examination in constant change, development, close interrelation and interdependence, as well as the application of the method of theoretical analysis.

3. In order to expand the acquired knowledge, it is possible to integrate the private methods of scientific knowledge classification, logical, problematic, as well as the historical-legal, the comparatively legal and the formal-juridical methods. They are combined with methods of system approach and functional approach.

\section{Conclusion}

In conclusion, it should be noted that the results of the analysis allow us to determine the purpose of the report as accomplished, the set tasks - as fulfilled, and the conclusions drawn - as the correct ones.

\section{References}

[1] Law on Defence and Armed Forces of the Republic of Bulgaria (Promulgated SG No. 100/20.12.2011, effective 1.01.2012), 52.

[2] Military Police Act, (Promulgated SG No. 48/24.06.2011., effective 24.06.2011), 4.

[3] Military Training Concept for MoD (Sofia: MoD Publ., 2013), 19.

[4] Penal code (Promulgated SGNo. 26 of 2 April 1968, amend. SGNo. 101 of December 19, 2017), 23.

[5] Alison M, Marwitz M., Teaching Creatively: Ideas in Action. Outernet: Eden Prairie, 2001, 37.

[6] Bligh D. A., What's the Use of Lectures?, Jossey-Bass Publ., San Francisco, 2000, 83.

[7] GaëlleFerré. Gesture, Intonation and the Pragmatic Structure of Narratives in British English Conversation. York Papers in Linguistics, York: Department of Language and Linguistic Science, University of York, 2005, 2, 55-90.

[8] Rosenshine B., Principles of Instruction. Research-Based Strategies That All Teachers Should Know, American Educator, Spring, 2012, 12.

[9] Osbourne A., How to "Think Up". New York, London: McGraw-Hill Book Co., 1942.

[10] Gordon W.J.J., Synectics: The Development of Creative Capacity, Harper \& Brothers, 1961, 28.

[11] Pearl J., Heuristics: Intelligent Search Strategies for Computer Problem Solving, New York, Addison-Wesley, 1983, 162.

[12] Constitution of the Republic of Bulgaria, in force since 13.07.1991, promulgated SG No. 56 of 13 July 1991, amended SG No. 12 of February 6, 2007.

[13] Code of Criminal Procedure (Promulgated SGNo. 86 of 29 April 2006, amend. SGNo. 7 of January 19, 2018), 8. 